\title{
PRECARIOUS INTELLECTUALS: THE FREELANCE ACADEMIC IN MALAYSIAN HIGHER EDUCATION
}

\author{
Alicia Izharuddin \\ Faculty of Arts and Social Sciences, University of Malaya, Kuala Lumpur, \\ MALAYSIA \\ Email: alicia@um.edu.my
}

Published online: 28 September 2018

To cite this article: Alicia Izharuddin. 2018. Precarious intellectuals: The freelance academic in Malaysian higher education. Kajian Malaysia 36(2): 1-20. https://doi.org/10.21315/km2018.36.2.1

To link to this article: https://doi.org/10.21315/km2018.36.2.1

\begin{abstract}
What is the impact of the rising class of the academic precariat - defined as academic workers contracted to teach and conduct research on short-term, zerohour contracts - on Malaysia's rapid industrialisation of higher education? This article seeks to illuminate the employment pattern of this growing class of insecure academic labour at a time when there is a decline in tenured appointments and academic positions for new PhD graduates in Malaysia. The work environment of the academic precariat is characterised as flexible at best and exploitative at worst; an average academic precariat may experience a drop in wages commensurable with their qualification and experience, lack of employment benefits and office hours, and "docility" under the disciplinary management of a neoliberal institution. This article also seeks a sensitive reading of how freelance academics understand themselves by highlighting their affective or emotional labour and whose experiences are specifically shaped by insecurity, vulnerability and uncertainty. Taking a sociological approach to examining this phenomenon, this article argues that the rise of the academic precariat can be attributed to the discursive climate within and at the peripheries of Malaysian higher education that operates alongside the restructuring of funds into higher institutions of learning. Such a discursive climate surrounds the unstable semantic reproduction of the designation "academic" and its catch-all usage to describe individuals within and at the peripheries of academia. Arguing that the rise of the academic precariat is a bleak indication of the state of higher education in Malaysia, this article closes with strategies for mobilising resistance and marshalling support through the strengthening of unions for full-time, part-time and freelance academics.
\end{abstract}

Keywords: Precarity, neoliberalism, higher education, academics, Malaysia 


\section{INTRODUCTION}

As a junior academic who is committed to full-time academic labour during the normalisation of corporate managerialism in Malaysian higher education (Lee, 2004), I have taken special interest in the variegated quality of the landscape of labour in Malaysian academia. This variegated quality is not isolated to Malaysian academia but rather is a reflection of the uncertainties and vicissitudes that punctuate the landscape of labour in Malaysia in recent years. Prior to my fulltime appointment as Senior Lecturer, I have performed, as a $\mathrm{PhD}$ student, a variety of contingent academic labour from part-time lecturing, facilitating tutorials, marking essays and Master's dissertations, and preparing exam and assignment questions for a number of universities including my own. During an intense but mercifully brief period of juggling multiple academic jobs and the $\mathrm{PhD}$, I quickly became aware that I was participating in a form of casualised academic labour that would persist for many of my colleagues even after receiving their $\mathrm{PhD}$. Before being appointed to a full-time academic position, many academics would commit to low paid, contingent and freelance academic labour. Such precarious forms of academic work presently characterise an expanding "underclass" within the academic profession.

Now located in the Gender Studies Programme in a public institution of higher education, I have begun to better appreciate my field's contribution to the scholarship and activism in academic labour in higher education. As a field sensitive to power relations in knowledge production and critical to the reproduction of inequality, scholarship in Gender Studies has critiqued the marketisation of higher education, "academic capitalism", and the rise of the corporate university. Situated within the social sciences and humanities, Gender Studies is subject to the destabilising conditions and market logic of corporatisation. However, this is not to say that instability within the academy is new to Gender Studies. Since its inception, Gender Studies has been shaped by a "history of institutional liminality and transgression of disciplinary boundaries" (Adsit et al., 2015: 27) which makes it an especially appropriate framework from which to examine, critique and challenge the normative conditions of precarity within higher education.

\section{TEACHING AND RESEARCH IN MALAYSIAN HIGHER EDUCATION DURING NEOLIBERAL TIMES}

It is no accident that the corporatisation of the university coincides with the accelerated reinvention of higher education in Malaysia as a business. Malaysia has been hailed as the region's major hub in higher education (Blessinger and Sengupta, 2012), thanks to a major restructuring to lure local students to remain within its 
shores, although Malaysia continues to be among the top senders to universities abroad. Investment in higher education came at a moment when Malaysia became among the world's biggest senders to foreign universities and colleges, and the subsequent "brain drain" in the academic and labour market more generally. This commitment to retain local graduates is witnessed in the rapid expansion of public and private universities and colleges across the country. Such solutions have been regarded in favourable terms as the "democratisation" and "massification" of higher education, connotations that suggest increased accessibility albeit for the majority with the financial means and demonstrated abilities. Related to solutions to stem the "brain drain", the booming of the higher education "industry" seeks to redress the inequality of access to higher education in Malaysia. Preferential access to public university and scholarships based on ethnicity has resulted in legal and political intervention to build more institutions of higher education for under-represented Malaysian youth. As Lee succinctly states, Malaysian higher education has reinvented itself from "elite to mass higher education, from higher education as a public service to higher education as a commodity and from the role of the state as provider to that of regulator..." (Lee, 2003: 137).

Expansion of tertiary education in Malaysia has taken a state-directed intervention defined by privatisation of higher education and the corporatisation of public universities (Lee, 2003; 2008; Mok, 2010). Privatisation refers to the fiscal restructuring from heavy reliance on state funding to the courting of corporate entities and community shareholders. Corporatisation meanwhile is characterised by the replacement of traditional governance by corporate managerialism. As argued by Ross (2009), the intensifying competition in the global market for higher education and the decreasing security of a teaching career have sparked an "explosive rise in cross-border traffic among students, teachers and investment capital" (Ross, 2009: 189). Within the context of Malaysian public universities, the advent of corporatisation can be traced to the amendment of the Universities and Colleges Act 1975. Lee (2004) demonstrates this emerging trend towards corporatisation in her case study of Universiti Sains Malaysia (USM) whereby the university's 300-strong member of the Senate comprised mostly academics has shrunk to 40 members. These changes reflect the watchwords of the restructuring of Malaysian higher education since the 1990s - accountability, efficiency and productivity.

The path towards corporatisation continues unabated with the long term government framework (Ministry of Education Malaysia, 2015) to further increase access to higher education and research publication and citation rates in a bid to rise in the global university league tables - but with decreasing reliance on government funding. Towards this end, the identity of the full-time academic has been redefined to "publish or perish" and whose performance is measured along metrics particular to a university. In Malaysian Research Universities (MRUs), 
each full-time academic is contracted to publish research annually in at least one to two high-impact, peer-reviewed journal articles, or one book published by an academic press, or two to three book chapters. While research publication is welcomed by some as a key performance indicator to distinguish an academic who demonstrates "impact" from the "unproductive" academic according to neoliberal labour measures, its higher goal - global rankings - is not without critique. The uncritical embrace and obsession with performance in global rankings simply demonstrate the critical role of higher education in national economic growth, security, and wealth production. Far from a well-oiled machine, strategies to improve a university's position have unleashed an array of problems that threatens academic quality and integrity (see Hazelkorn, 2011; Gruber, 2014). To name but a few, publications and citation counts can be easily gamed and manipulated by the ever-expanding shadowy industry of fake and predatory journals.

Table 1: Academic staff in public institutions of higher education in Malaysia (2014 and 2015)

\begin{tabular}{|c|c|c|c|c|}
\hline \multirow{2}{*}{$\begin{array}{l}\text { Public institution of } \\
\text { higher education }\end{array}$} & \multicolumn{2}{|c|}{2014} & \multicolumn{2}{|c|}{2015} \\
\hline & $\begin{array}{l}\text { Part-time female } \\
\text { academic staff }\end{array}$ & $\begin{array}{l}\text { Part-time male } \\
\text { academic staff }\end{array}$ & $\begin{array}{l}\text { Part-time female } \\
\text { academic staff }\end{array}$ & $\begin{array}{l}\text { Part-time male } \\
\text { academic staff }\end{array}$ \\
\hline $\begin{array}{l}\text { Universiti Kebangsaan } \\
\text { Malaysia }\end{array}$ & 7 & 7 & 0 & 0 \\
\hline $\begin{array}{l}\text { Universiti Malaysia } \\
\text { Sabah }\end{array}$ & 0 & 1 & 0 & 0 \\
\hline $\begin{array}{l}\text { Universiti Malaysia } \\
\text { Perlis }\end{array}$ & 0 & 1 & 0 & 1 \\
\hline $\begin{array}{l}\text { Universiti Malaysia } \\
\text { Sarawak }\end{array}$ & 7 & 3 & 3 & 0 \\
\hline $\begin{array}{l}\text { Universiti Sultan Zainal } \\
\text { Abidin }\end{array}$ & 103 & 37 & 93 & 40 \\
\hline
\end{tabular}

Source: Ministry of Higher Education Malaysia (2015).

Although the number of public institutions of higher education (Institut Pengajian Tinggi Awam, or IPTA) is smaller (20) in relation to private ones (Institut Pengajian Tinggi Swasta, or IPTS) (104 with university status and 405 with college status (Ministry of Higher Education Malaysia, 2014), the IPTA sector hires a much greater number of academic staff. In 2013, there were 32,516 academic staff, 11,838 of which have doctorates in contrast to 24,476 IPTS academic staff members in total. The breakdown of part-time lecturers in IPTA in Table 1 in selected universities is shown below. Table 2 showed the number of full-time and part-time teaching staff in IPTS in accordance with their highest 
qualification. Part-time lecturers in 2014 constitute nearly half of the total teaching staff in IPTS (Table 2). Both tables reveal the gender imbalance in part-time teaching staff and their respective qualifications. There are more women than men in part-time teaching positions in newer public universities in Malaysia such as Universiti Sultan Zainal Abidin where a more pronounced gender disparity in student enrolment exists (Ministry of Higher Education Malaysia, 2014).

The number of contingent academic workers who represent sessional lecturers, teaching assistants, tutors and research assistants is vaguer than certain as many are hired on an ad hoc basis and zero-hour contracts. Furthermore, the category of "academic precariat" discussed in this article covers a wide range of workers within and outside academia and thus is not situated neatly in the official numbers captured by the Ministry of Higher Education.

Table 2: Full-time and part-time academic staff in private institutions of higher education in Malaysia in 2014

\begin{tabular}{lcccc}
\hline $\begin{array}{l}\text { Highest academic } \\
\text { qualification }\end{array}$ & $\begin{array}{c}\text { Full-time female } \\
\text { academic staff }\end{array}$ & $\begin{array}{c}\text { Full-time male } \\
\text { academic staff }\end{array}$ & $\begin{array}{c}\text { Part-time female } \\
\text { academic staff }\end{array}$ & $\begin{array}{c}\text { Part-time male } \\
\text { academic staff }\end{array}$ \\
\hline PhD & 897 & 1,408 & 370 & 763 \\
Masters & 6,242 & 3,868 & 3,128 & 4,226 \\
Bachelors & 4,902 & 2,686 & 1,486 & 1,948 \\
Diploma & 439 & 374 & 76 & 83 \\
\hline
\end{tabular}

Source: Ministry of Higher Education Malaysia (2014).

This article utilises in-depth interviews to examine the quality and experience of freelance academic labour and argues that the rise of the academic precariat can be attributed to the discursive climate within and at the periphery of Malaysian higher education that operates alongside the restructuring of funds into higher institutions of learning. Such a discursive climate surrounds the unstable semantic reproduction of the designation "academic" and its catch-all usage to describe individuals within and at the periphery of academia. It can also be argued that the academic precariat is an incipient phenomenon, not quite a class and likely to be an under-reported form of work in Malaysian academia due to the limits on the discursive landscape mentioned above.

Seven individuals from the social sciences, humanities and the hard sciences who are currently and formerly freelance academics in Kuala Lumpur and Selangor are presented here as personas operating in the discursive margins of the discourse on higher education in Malaysia today. They participated in in-depth, semi-structured interviews and were asked the following questions: 
1. What have been the challenges and opportunities of freelance academic work?

2. What have been their primary emotional states that emanate from the precarious nature of their freelance/part-time academic work?

3. What constitutes better and fair working conditions for freelance and parttime academics in Malaysia?

Their responses, along with key data on the number of part-time academics in Malaysia, provide an exploratory sketch of freelance academic labour in Malaysia. One is able to draw certain continuities between freelance academics and adjuncts or casualised academics in North American, British and Australian universities as a means of proposing solutions for the improvement of work conditions and career prospects. There are continuities insofar as freelance academics in Malaysia are at the margins in a two-tier system whereby they are economically and politically disenfranchised.

The freelance academics in Malaysia hail from a variety of disciplines and report an admixture of challenges and opportunities that arise from working contingently within academia and without institutional affiliation. The prominence of freelance academic labour in higher education in its present form brings into stark relief the transformation in employment patterns from security to uncertainty and precarity. In fact, the freelance academic worker examined in this article report diverging professional divergences that have implications on their financial health and wellbeing. As an exploratory study of freelance academics in Malaysia, it constitutes an early challenge against precarious academic labour and the culture of "contingent" faculty in the Malaysian context.

\section{Is the Freelance Academic the Academic Precariat?}

What is the impact of the rising class of the freelance academic - defined as academic workers contracted to teach and conduct research on short-term, zerohour contracts - on Malaysia's rapid industrialisation of higher education? What is the material reality of performing precarious academic labour? The term "precariat" popularised by Guy Standing is used to describe a "dangerous class" of workers at the margins of a globalised market logic. Defined by its root word "precarious" the precariat are represented by a burgeoning rank of workers on temporary and short-term contracts. Precariousness and lack of job security have affected the milestones of adulthood. Younger people are now more likely to live with their parents after graduation, marry and own a home later than their parent's generation (Standing, 2011: 111). The term "precariat", however, has been taken to task for its Eurocentrism in its genealogical assumptions (Matos, 2012; Munck, 
2013). Seymour (2012) argues that the "precariat" is not only an empirically but also a theoretically under-developed concept. For Seymour, the creation of a single category of a "new" type of worker lends a "false homogeneity to atypical employment" (Seymour, 2012). However, I would like to propose that "precariat" is nonetheless instructive in categorising the group of workers whose relationships with academic labour are reproduced by a global and globalised restructuring of higher education. The intention of adopting the neologism "precariat" is not, as Munck (2013) states, to introduce anything particular new about academia in Malaysia but rather to call to attention and illuminate an entrenchment of precarious labour within higher education.

The literature places a range of academic workers under the umbrella of "precariat" Academic precariat's include adjuncts, part-time lecturers, facilitators, fractional staff and graduate teaching assistants who perform outsourced work for the academy. Highly-paid consultants who are paid for their services in institutions of higher education, however, do not belong to the academic precariat. Rather than an appointment to a full-time position that comes complete with a standard job description of teaching, research and administration, employment and institutional benefits, pension scheme, access to university resources and personal office, the freelance academic may only perform fragments or fractional aspects of the "traditional" academic role. Thus, as "contingent" staff the hiring of the academic precariat is contingent on the institution's budget, enrolment, or both. They are also not contracted to perform and be evaluated by senior management. It is perhaps no surprise that the incipient rise of the academic precariat coincides with the massification of higher education. Despite rising tuition fees and high student enrolment, the freelance academic is paid a minimal salary to teach one or two courses in a semester, prepare materials for evaluation such as exam questions and assignments. Freelance academics resemble part-time academics and adjuncts in the US, Canada and the UK where more and more academic work is performed by people hired on a per course basis. However, while still under-researched, the scale of this form of contingent labour in Malaysia is less pronounced than its counterpart in the North.

Those who have been interviewed herein demonstrate the complex relationship between the changing landscape of employment within higher education in Malaysia and institutional priorities that emphasise quantifiable accountability, efficiency and productivity. They comprise researchers with a $\mathrm{PhD}$ or Masters degree who have left higher education institutions after establishing their careers in academia or graduate students seeking supplementary income. Others are designated as independent researchers and former full-time academics without a university affiliation. Indeed, the sheer range of the freelance academic workers poses its own host of challenges beyond definitive categories including its historical specificities as pointed out by Matos (2012). In addition, as I will argue in 
further detail below, the broad designation of the freelance academic as belonging to the academic precariat works in mutual reinforcement with the looseness of the term "academic" and "lecturer" in Malaysia.

The work environment of the academic precariat is characterised as flexible at best and exploitative at worst. An average academic precariat may experience a drop in wages commensurable with their qualification and experience, lack of employment benefits and office hours and "docility" under the disciplinary management of a neoliberal institution. Precarious academic labour, as my informant Selvam, 31, tells me, is not sustainable. In fact, it is for him a degrading form of labour. Unlike permanent staff, freelance staff have significantly fewer rights as a worker. In his capacity as a part-time lecturer in a private college in Selangor where he teaches architecture, he will not be entitled to paid leave, medical claims, compensation, bonus or much influence in faculty administration. Part-time lecturers "are just there to do the job and leave." Without their fulltime appointment and membership in the faculty, freelance and part-time lecturers cannot participate in departmental meetings nor have autonomy over their work. Writing in 2003, Molly Lee describes the variety of part-time lecturers who subsist on several part-time lecturing positions in different private colleges. The discursive shift towards the construction of the student as "consumer," "customer" and "client," has meant that in private institutions where student enrolment and "satisfaction" are high on the managerial agenda, the student is given preferential treatment over lecturers who are simply "service providers" (Lee, 2003).

As a side effect of the "cost-effective" approach to managing higher education, poverty and financial stress characterise the indictment of the material reality of the academic precariat who teach. In many universities and colleges across the US where more than half of faculty consist of "contingent" faculty, adjuncts subsist on food stamps and live below minimum wage. Contingent academics who swell the ranks of the adjunct are ABDs (All But Dissertation) graduate students and recent holders of a PhD. A similar though less acute situation is experienced in Malaysia. For Anne, 43, a freelance academic in geography, maintaining a livelihood as a freelancer is a challenge. Like freelancers in other fields, her income is less predictable. But unlike freelancers in profit-oriented sectors, her services and skills are not always so lucrative. The disempowerment of the academic precariat who work within the margins of higher education can be attributed to the trends that follow the expansion of higher education. Along with the explosion in student numbers comes the corresponding rise in administrative staff but not necessarily teaching staff. As Lee (2003) notes, this explosion is seen to require the support of an extensive bureaucratic class who display significant power in the everyday administration of the university. As the notion of the university is transformed from a place of learning and personal growth to a business enterprise where education is 
a commodity to be bought for a (high) price, the role and priorities of the academic are thus transformed.

In the commodified university, the ability of the academic to teach and entice students as "consumers" of education becomes paramount. In most universities and colleges throughout Malaysia where research output is less a priority than teaching, the intellectual curiosity of the academic to engage in research and develop their knowledge communities is de-emphasised or discarded altogether. Innovations in teaching and learning such as distance learning and the use of online learning environment have further destabilised the traditional role of the academic as an instructor who teaches in the classroom and lecture theatres. It appears that emphasis on online learning and virtual learning environments to maintain a seamless connection between spaces for teaching, learning, monitoring and assessment frequently has an inverse relationship with the physical properties of academic life. Many part-time lecturers in both public and private universities lack a desk and office space of their own which means that their professional ties with their institution hinges only on the contact time with students during lectures and tutorials in the classroom.

The academic profession in Malaysia consists of faculty ranked in a combination of British and American nomenclature of tutor, lecturer, senior lecturer, associate professor, and professor. Academics in public institutions of higher education belong to the civil service who receive wages that correspond to the salary structures of the national civil service. With the recommendation of the faculty and having fulfilled aspects of their employment to a satisfying degree, such as publications in prestigious journals, she will be offered tenure and made a permanent member of staff in the faculty until retirement. Retired professors may continue in the profession on a temporary and contract-by-contract basis in addition to receiving a government pension. Under the paradigm of corporate managerialism, academics in both public and private universities are reinvented as "entrepreneurs" and they are pressured to find income-generating ventures for their department and faculty. The marketisation of higher education has, as Lee (2003) rightly notes, created a "cleavage" between academics in the sciences and those in the social sciences and the humanities. Both face pressure to commoditise their research through patenting and consulting industries. However, while there is a closer relationship between the sciences and industry, academics in the social sciences and the humanities feel their value in knowledge production is undermined by the university's profit-oriented priorities.

In the Malaysian context, freelancing within the margins of public and privately run institutions of higher learning bears different material working conditions. Selvam has both worked as a part-time lecturer in a public university where he felt his salary of RM100 to RM150 per hour was commensurable to his 
efforts and qualifications. However, he states that payments are frequently delayed by red tape. In one incident he was not paid for four months which exacerbated his financial situation. In his current part-time employment as lecturer, he is paid only half of his previous salary but payments are timely. There are also instances in which full-time research appointments are conceived as precarious academic labour. Formerly affiliated as a postdoctoral fellow in a public university in Malaysia, Tina, 39, laments the heavy demands made on postdoctoral researchers to produce research-based outputs within a timeframe of one-year contracts. Although appointed and remunerated as a full-time but not permanent member of staff, other terms of her appointment such as lack of health benefits and full library borrowing privileges were made commensurable only to a part-time position. Tina's experience as a full-time postdoctoral researcher in a public Malaysian university can also be defined as highly precarious: having failed to produce five articles in journals indexed in the International Scientific Indexing (ISI) bibliographic database system within her one year of employment, her contract was abruptly terminated. Both Selvam and Tina's experience underline the reinvention of the academic in the corporate university as producers of measurable commodities leaving little room for the significance of affective labour in academia.

\section{AFFECTIVE LABOUR AS ACADEMIC LABOUR}

Focus is given in this article to affective labour invested in freelance academic work. How do freelance academics feel about their position at the fringes of the university? Why should emotions and affect matter when addressing the conditions of freelance academic work in Malaysia? Literature on work and affect in neoliberal times point to the emphasis on the individual's self-responsibility for their own subjectivity in which negative emotions are sequestered into private spaces. Feelings of anger, shame, frustration, vulnerability and despair are thus projected inwards. However, critics of the neoliberal management of affect have argued that "good emotions" of the happy worker are cultivated and rewarded while "bad" ones shunned and disciplined (Sara, 2012). Emotions and affective labour in academia, both good and bad, can be regarded as a "resource for intervention" into addressing inequality in the corporate university (Adsit et al., 2015: 25). It is a means of challenging assumptions of the inferiority of emotions to the superiority of the intellect. The representation of the freelance academic that foregrounds their affective engagement with their work conditions is a valuable resource for collective and institutional intervention.

Negative feelings against institutions are actively and implicitly suppressed within Malaysian higher education. In addition to the curtailment on politically sensitive research and teaching, students and all members of university staff are 
prohibited from participating in political and economic-based street protests, rallies and demonstrations under the controversial University and Colleges Act 1971, with multiple amendments between 1975 and 2012. The residual feelings that come with institutional injustices have been explored with depth by Sara (2012). In On Being Included, she states that the subjugation of such feelings often become normalised and institutionalised as "habit" (Sara, 2012: 26). Focused on workers who work on diversity within the university, Sara argues that strategies that aim to dismantle hegemony, privilege and homogenisation will leave behind a feeling of hitting a brick wall. The "brick wall" she refers to is a metaphor for the inertia within practices in institutions towards establishing equality, diversity, and inclusivity. Conversely, the "feeling" of freedom that comes with the notion of flexibility is often tinged with ambivalence for the freelance academic. Although the freelance academic would be regarded as the ultimate entrepreneurial scholar who is able to "sell" her labour in a growing market where education is a desirable commodity, institutional legitimacy and protection continue to become the overriding determinant of stability and academic freedom.

The conditions of freelance work means that freelance geographer Anne has greater flexibility through not being tied down to the traditional nine to five work cycle and time for personal pursuits becomes something she has more control over. Ownership of her "own time" offers affective respite from many years of full-time academic labour in public and private institutions of higher learning. By contrast, researcher in the medical humanities Mary, 41, describes the accompanying stress that defined her freelance academic labour in the years prior to her present fulltime appointment:

Throughout the 2.5 years, I lived in constant anxiety and stress. I kept thinking about my fixed term contract, while having to pay attention to the multiple freelance jobs I was doing. It had been both emotionally and physically draining, especially during days when I was afflicted by stress induced insomnia. Also, as I have mentioned earlier, I was at once freelancing for multiple jobs, not just one. One of the emotional challenges is related to switching focus while juggling between different jobs, because each job had its own specific demands. Though it has been my plan and aim to specialise in one or two academic areas that I was interested in, juggling between jobs made specialisation extremely tough to achieve as I had to constantly adjust to changing demands. In addition, I had to keep record of my own salary and paid months after the freelance jobs were completed.

The affective landscape of precarious labour is punctured with shame and stigma of having failed to attain the social mobility of previous generations through higher education (Matos, 2012). Precarious labour has instead led to a downward 
mobility characterised by debt, low wages, delayed marriage, family-building and home-ownership. Freelance academics must perform along and against different written and unwritten standards to demonstrate their worth. At times, permanent academic staff may participate in the marginalising of the academic precariat. As Selvam argues:

As such, treatment of their employment is casual and abuse of their rights is socially appropriate ("oh he's only a part-timer!"). Freelancers have to "claim" their pay rather than receive them as their right. In the process they find themselves constantly having to contact their administrators to ask (sometimes felt like begging), even had to be "extra polite" for fear of the proverbial Little Napoleons who could practice their dysfunctional work practice to sabotage one's claim! Failure to adhere to monthly deadlines can lead to delays of months - in fact delays of their payment is socially acceptable, perhaps even legal.

The structural feeling of marginality as opposed to a purely individual one does not emerge from the freelance academic but emanates from a "two-tiered" structure that separates secure, full-time and permanent staff from precarious, parttime and contingent staff. Such a feeling of marginality may well be perpetuated by assumptions that part-time and freelance academics are somehow "less serious, less intellectual, or less committed" (Adsit et al., 2015: 30). Freelance academics who are at the margins of the institution are at the mercy of the bureaucracy through a far more rigorous surveillance of attendance and productivity than the privilege enjoyed by contracted and permanent academic staff in a university or college. The marginalisation of the academic precariat results in the reproduction of marginality through the precariat's self-identification with oneself and others - "we're just part-timers at this and that university". By distinguishing oneself as "only" part-timers, precarious academic labour becomes devalued and loses its symbolic capital in a culture that delimits "real" academics as those appointed with a full-time teaching and research position. Unless addressed in strategies that highlight the inadequate working conditions, discussed in the final section, the affective quality of the freelance academic experience will continue to remain invisible within the discourse of higher education in Malaysia.

\section{ACADEMICS WITHOUT INSTITUTIONS OF HIGHER EDUCATION}

This section examines the discursive landscape of academic labour outside of higher education populated by academic workers without full-time affiliation to an institution of higher learning. In the semi-structured interviews, I discovered the paradox of the semantics of identification and belonging associated with the 
term "academic" as a job title. The term "academic" is frequently utilised, as I do here, to label individuals who perform academic or intellectual labour regardless of the latter's actual employment status and institutional affiliation or lack thereof. Meanwhile, freelance academics themselves are frequently reticent to avail themselves with the prestige of the job title as the realities of freelance academic labour often hamper strategies of belonging to institutions of higher education. Experiences that define freelance labour are not just semantic and discursive but can be diverse as particular privileges and access to resources are distributed unequally depending on one's expertise, experience and connections.

Concerns about research funding are particularly acute for scientists without institutional affiliation in Malaysia. Aliyas is a physicist who was previously a full-time faculty member of a private university in Malaysia but left to pursue a freelance scientific career. Without a full-time position in a university or research institution, Aliyas has relative freedom to pursue science, publish and mentor students. He relies on his affiliation with a British university that awarded his $\mathrm{PhD}$ to apply for international grants and currently co-supervises four $\mathrm{PhD}$ students from universities outside Malaysia. However, Aliyas complains that allocation for research in private universities in Malaysia is limited because teaching is heavily prioritised. As an independent researcher in the physical sciences, he is able to marshal his links with his British alma mater, research institutes and industry to secure research funding. Without such connections, support for grants would be more difficult, Aliyas argues.

Aliyas the research scientist demonstrates that it is possible to secure funding and conduct research without a university affiliation. Another researcher in public policy and Member of Parliament (MP), Richard, who manages a research institute in Selangor receives funding from political affiliations to conduct research and hire researchers. He pays his interns and one researcher with his MP salary. Like Aliyas, Richard reports few challenges in freelance academic labour. He attributes access and success to his former employment as a full-time academic in a local private university and networks in higher education. Even without university affiliation, he performs "traditional" academic labour - writing and publishing research in journals and speaking at conferences - with few barriers. It bears mentioning that both Aliyas and Richard acquire access to research funding outside the mainstream channels typically utilised by public and private higher institutions. The Ministry of Higher Education is the main funding organisation for academics with full-time university appointments.

Both Aliyas and Richard personify the idealised flexibility and freedoms that freelance academic work brings to "shape and coordinate one's 'own' work and one's 'own' life" (Beck, 2000: 53). Conversely, part-time researchers and sessional lecturers like Yuet Li struggle to conduct research outside the confines of an institution of higher education. She currently teaches a few times a week 
in a private college and is hired by a consultancy firm focusing on public policy. Being in public policy like Richard, Yuet Li highlights the challenge of academic freedom when operating outside the university. Most research in public policy in Malaysia is funded by political parties and banks. Reliance on work funded by parties with vested interest can hamper the pursuit for individual interests in research and critical freedom. Being awarded grants from public sources and nonpolitical or commercial stakeholders is not sustainable, argues Yuet Li, as "the general public does not value this kind of research [in public policy]."

Within this site that decouples academic labourers from the university exists the fast and loose ways of academic performativity and subjectivities. The "academic" is a term that crosses the formal vocation of the lecturer and researcher and that of the broader definitions of academic labourer who join the ranks of postgraduate students, adjuncts, independent researchers and part-time and freelancing sessional lecturers and tutors. Thus, the discursive landscape of academic labour that defines who the "academic" is exemplifies the way semantic slippage and prestige of the academic profession operate in tandem. Perhaps as a reflection of elitism, there is resistance amongst academics against self-identifying with terms such as "workers" and "employees" (Tirelli, 1997) which can impede attempts at unionisation, an issue I discuss in the next and final section. There is still prestige attached to the formal position of lecturer and professor even when the full-time appointments, tenure positions and living standards of the professional academic have declined. This is because, as Bourdieu has observed in Homo Academicus, the university comprises "institutions entrusted with the transmission of legitimate culture and invested because of this with a social function of consecration and conservation, they are places of specifically social powers..." (Bourdieu, 1988: 84).

As pointed out by Love (2007), job titles matter. For academic workers situated at the disadvantaged end of a lop-sided field of academic power relations, their job titles contribute to and are an effect of the two-tiered system where adjuncts who are known as "gypsy scholars" and "migrant scholars" and as a consequence are treated as second class. For freelance geographer Anne, she does not claim the title "academic" for herself as she does not have students or workplace colleagues. Being an academic, she argues, requires one to commit to three fundamental roles of teacher, researcher and administrator. Without these traditional roles, she is cast adrift in the unpredictable landscape of freelance work. Similarly for Yuet Li, being an "inexperienced researcher" she does not identify with the title "academic." 


\section{THE WAY FORWARD? MOBILISING ACADEMIC WORKERS}

The emergence of precarious academic labour is an indictment of the neoliberal logic that has defined Malaysian higher education today. As a major education hub in Asia, Malaysia is known for its openness to international higher education (Morgan, 2016) as demonstrated by the establishment of international campuses of British and Chinese universities and the enrolment of international students. Internationalisation as a feature of research universities takes its cue from the idealised Emerging Global Model (Mohrman, Ma and Baker, 2008) based on universities in the United States (Camacho and Rhoads, 2015). As I have discussed above, there are several continuities between the freelance academic in Malaysia and adjuncts in American and Canadian universities. The direction towards corporatisation of higher education in Malaysia has resulted in the fiscal restructuring of universities and colleges. This has meant reconstruction of university leaders as CEOs, students as consumers, teaching staff as "service providers", and education as commodity. Researchers meanwhile are hired like contractors on contracts as short as six months to conduct and produce research. In more degraded worker conditions of freelance and independent researcher, their labour is akin to that of the expendable mercenary who could produce high quality research articles on demand.

The work of the freelance academic offers a portrait of flexibility and freedom. They enter rapidly in and out of contracts performing specific tasks and often engage minimally with institutions of higher education. Such terms of their employment frequently result in the justification for lower wages and few to no employment benefits and decision-making rights in administration. Resistance and protest against existing practices and hierarchies within higher education risks loss of employment, poverty and barriers to mobility due to difficulty in attaining recommendation from employers.

This closing section highlights ways of mobilising academic workers, both full-time and part-time freelancers towards better work conditions, fairer contractual agreements and intellectual support for research. Previous studies have demonstrated the effectiveness of unions beyond the attainment of fairer wages and benefits (Freeman and Medoff, 1979; Medoff, 1979; Yates, 2009). Alternative to traditional union alliances, strikes and walkouts are strategies like storytelling and organic theatre (Adsit et al., 2015; Kannan, Schicke and Doe, 2015) and semantic resistance such as rejecting the term "lecturer" or "professor".

It is as yet uncertain what strategies freelance academics in Malaysia can turn to beyond forming alliances with members of university workers' unions. With the exception of two public universities, Universiti Malaya (UM) and Universiti Sains Malaysia (USM), there are no official in-house unions for academic staff in Malaysian universities. Unions do not attract many members from the academic 
profession. As civil servants, academics in public universities are expected to tow the government line and not challenge its employment policies. There are agitations to abolish the University and College Act 1971 but pressures from within the academy are muted. Despite the restructuring of higher education in Malaysia to make it less financially dependent on public funds, the political deference to government authority overdetermined the lack of intellectual and political autonomy of universities. There are fundamental political barriers and economic imperatives that may make the mobilising of the academic precariat unfeasibly utopian. Although there are occasional agitations against the restructuring of academic labour, such as the introduction and imposition of separate service tracks that denote emphasis and performance evaluations such as "standard" division of teaching and research, "teaching" and "research", tracks, protest against the precarity and liminality of certain forms of academic labour is much more muted as to be non-existent. In fact, inter-university initiatives like the Malaysian Academic Movement or GERAK does not have an agenda specific to the protection of the academic precariat in its on-going campaign for academic freedom in Malaysian higher education. Without addressing the specificities and multifaceted aspects of contingent academic work, GERAK does, however, promote the security of tenure as one of the guarantees of academic freedom.

There are indeed challenges that lie ahead of mobilising for better work conditions for the freelance academic that are different from other forms of labour that seek similar demands. In a march towards privatisation and commercialisation, universities have become the site in which intellectual labour is "hyper-individualised" (Camacho and Rhoads, 2015) which makes communitybuilding and collective bargaining a challenge. Teaching in higher education has traditionally been regarded as middle-class, white collar work with high social status and cultural capital. With the exception of precarity, lower pay and lack of benefits, freelance academics enjoy access to the hallowed spaces of the privileged. Moreover, academic labour within higher education is often framed as a form of "exceptionalism" whereby overwork with few returns or compensation is regarded as a sacrifice to the vocation. However, as Camacho and Rhoads (2015) note, assumptions of exceptionalism simply reinforce the myth that academia is a traditionally democratic and egalitarian space.

The demands that the freelance academic makes are by turns rights and privileges that are associated with being a member of faculty. This means the peace of mind that comes with a clear, fair and negotiable contract and pay that are commensurate with experience and an office to perform multiple academic tasks. Seeing academic labour as constitutive of the ecology of higher education, improved academic work conditions will improve the quality of student teaching and learning. This means that for part-time freelance academics, fair remuneration 
of contact hours that extend beyond face-to-face lectures for the preparation of teaching materials and personal appointments for pedagogical guidance. Semantic rethinking is necessary to question the prestige intrinsic to the job title "academic" or "lecturer". Such rethinking is necessary to promote inclusivity and belonging to a profession and vocation rather than just to an institution. However, Adsit et al. (2015) would argue otherwise and propose that notions of "belonging" may be more exclusive than we realise and therefore unsustainable when transience and mobility across institutions and disciplines are necessary for individual academics. Adsit et al. (2015) states that the need for "belonging" within an institution and disciplinary community can sometimes mask the privilege of a select few who belong long-term in such spaces.

Finally, against the ideological inclination towards hyper-individualisation of academic work is the formation of communities for freelance academics. In her "Manifesto for the freelance academic", Katie Rose Guest Pryal presents strategies to re-empower freelance academics in their employment. The manifesto re-appropriates the meaning of contingency in which freelance academics "hold the power" in the rigid hierarchies of university and college life (Pryal, 2014). In the five-point manifesto, the freelance academic must be paid for their work and prioritise the "love" of geographical location in which one works and where support systems exist. For Pryal, the freelance academic may want to abandon attempts to embrace the paradigm of corporate academia because of the low likelihood for universities, particularly in North America, to hire permanent academic workers. Community building and the practice of healthy cynicism when hired in a parttime and contingent capacity constitute the manifesto's remaining strategies.

A localised manifesto for freelance academics in Malaysia that takes into account the limits of political action within higher education, diminishing institutional resources, and demands on individual "productivity" will begin with an overdue critique of the largely unchallenged ethos of higher education as a business. The price paid by individuals with advanced degrees at the margins of academic labour under such an ethos is a personal crisis ignored by state and institutional stakeholders. Before "adjunctification" becomes the prevailing logic of Malaysian higher education, the entire class of academic workers - temporary, part-time, and full-time - needs to establish a singular voice of solidarity in the face of relentless corporatisation, individualisation, privatisation, and the quixotic obsession with rankings. Although competition for diminishing resources presently defines Malaysian higher education, collective solidarity for improved working conditions, redistribution of labour, and commensurable compensation will benefit freelance and full-time academics alike across all types of institutions of higher education without which the paradigm of neoliberalism will continue to impoverish all. 


\section{CONCLUSION}

The respondents in this study express both reticence and optimism about the landscape of academic labour in Malaysia. When asked what would be an accomplishable ideal to improve the work conditions of freelance academics and independent researchers, Anne says it is "a difficult question to answer." The unabated movement of higher education towards corporatisation, commodification and globalisation has set into motion particular affective strategies of highly skilled and educated workers. Such affective strategies comprise a range of possibilities and limitations for academics who labour under the sign of precarity. For Tina, her experience as a postdoctoral researcher and accumulation of sophisticated intellectual labour are regarded as mobile and transferable outside academia. As such, her optimism underscores the redeeming feature of freelance academic work that coincides with one of the nobler purposes of higher education: mobility. This paper is simply a beginning of a continuing conversation with precarious freelance academics in Malaysia and their struggles. It is my hope that more attention to the affective and embodiment of precarious labour within higher education will generate transformative employment policies in Malaysia that are couched in the language of fairness and justice.

\section{REFERENCES}

Adsit, J., S. Doe, M. Allison, P. Maggio and M. Maisto. 2015. Affective activism: Answering institutional productions of precarity in the corporate university. Feminist Formations 27(3): 21-48. https://doi.org/10.1353/ff.2016.0008

Beck, U. 2000. The brave new world of work. Cambridge: Polity Press.

Blessinger, P. and E. Sengupta. 2012. Is Malaysia the regional leader in international higher education? The Guardian. https:/www.theguardian.com/higher-educationnetwork/blog/2012/jul/02/higher-education-in-malaysia (accessed 9 July 2016).

Bourdieu, P. 1988. Homo academicus. Stanford: Stanford University Press.

Camacho, S. and R. A. Rhoads. 2015. Breaking the silence: The unionization of postdoctoral workers at the University of California. The Journal of Higher Education 86(2): 295-525. https://doi.org/10.1353/jhe.2015.0010

Freeman, R. and J. L. Medoff. 1979. The two faces of unionism. The Public Interest 57: 69-93. https://doi.org/10.3386/w0364

Gruber, T. 2014. Academic sell-out: How an obsession with metrics and rankings is damaging academia. Journal of Marketing for Higher Education 24(2): 165-177. https://doi.org/10.1080/08841241.2014.970248

Hazelkorn, E. 2011. Measuring world-class excellence and the global obsession with rankings. In A handbook on globalization and higher education, eds. S. Marginson, R. Naidoo and R. King, 497-515. Cheltenham, UK: Edward Elgar. https://doi. org/10.4337/9780857936233.00040 
Ivancheva, M. P. 2015. The age of precarity and the new challenges to the academic profession. Studia Europaea 1: 39-47.

Kannan, V., J. Schicke and S. Doe. 2015. Performing horizontal activism: Expanding academic labor vocacy through beyond a three step process. Literacy in Composition Studies 3(1):131-142. https://doi.org/10.21623/1.3.1.11

Lee, M. 2008. Restructuring higher education: Public-private partnership. Journal of Asian Public Policy 1(2): 188-198. https://doi.org/10.1080/17516230802094494 2004. Global trends, national policies and institutional responses: Restructuring higher education in Malaysia. Educational Research for Policy and Practice 3: 31-46. https://doi.org/10.1007/s10671-004-6034-y

2003. The academic profession in Malaysia and Singapore: Between bureaucratic and corporate cultures. In The decline of the guru: The academic profession in developing and middle-income countries, ed. P. G. Altbach, 135-165. London: Palgrave Macmillan.

. 1996. Reforms in higher education in Malaysia. In Reforms in higher education, ed. K. Watson, 195-205. London: Bloomsbury

Love, C. 2007. Adjuncts with power: Making policy in university governance. In Gypsy scholars, migrant teachers and the global academic proletariat: Adjunct labour in higher education, eds. R. Teeuwen and S. Hantke, 59-70. Amsterdam and New York: Rodopi.

Matos, P. 2012. Call centre labor and the injured precariat: Shame, stigma and downward social mobility in contemporary Portugal. Dialectical Anthropology 36: 217-243. https://doi.org/10.1007/s10624-012-9276-8

Medoff, J. L. 1979. Layoffs and alternatives under trade unions in US manufacturing. The American Economic Review 69(3): 380-395.

Ministry of Education Malaysia. 2015. Executive summary Malaysia Education Blueprint 2015-2025 (Higher Education). Putrajaya: Ministry of Education Malaysia. https://www.um.edu.my/docs/default-source/about-um_document/media-centre/ um-magazine/4-executive-summary-pppm-2015-2025.pdf?sfvrsn=4

Ministry of Higher Education Malaysia. 2015. Statistics of private higher education institutions (PHEIs). Putrajaya: Ministry of Higher Education Malaysia.

2014. National education statistic: Higher education sector. Putrajaya: Ministry of Higher Education Malaysia.

Mohrman, K., W. Ma and D. Baker. 2008. The research university in transition: The emerging global model. Higher Education Policy 21: 5-27. https://doi. org/10.1057/palgrave.hep.8300175

Mok, K. H. 2010. When state centralism meets neo-liberalism: Managing university governance change in Singapore and Malaysia. Higher Education 60(4): 419-440. https://doi.org/10.1007/s10734-009-9307-9

Morgan, J. 2016. Germany and Malaysia "top performers" for internationalization. Times Higher Education. https://www.timeshighereducation.com/news/germany-andmalaysia-top-performers-for-internationalisation (accessed 13 September 2016).

Munck, R. 2013. The precariat: A view from the South. Third World Quarterly 34: 747-762. https://doi.org/10.1080/01436597.2013.800751 
Pryal, K. R. G. 2014. A manifesto for the freelance academic. Chronicle Vitae. https://chroniclevitae.com/news/783-a-manifesto-for-the-freelance-academic (accessed 27 September 2016).

Ross, A. 2009. Nice work if you can get it: Life and labor in precarious times. New York and London: New York University Press. https://doi.org/10.18574/ nyu/9780814776292.001.0001

Saccaro, M. 2014. Professors on food stamps: The shocking true story of academia in 2014. Salon. 21 September. http://www.salon.com/2014/09/21/professors_on_ food_stamps_the_shocking_true_story_of_academia_in_2014/(accessed 14 July 2016).

Sara Ahmed. 2013. The cultural politics of emotion. New York and Oxford: Routledge. 2012. On being included: Racism and diversity in institutional life. Durham: Duke University Press.

Seymour, R. 2012. We are all precarious - On the concept of the "precariat" and its misuses. New Left Project. http://www.newleftproject.org/index.php/site/article comments/we_are_all_precarious_on_the_concept_of_the_precariat_and_its_ misuses (accessed 18 August 2016).

Standing, G. 2011. The precariat: The new dangerous class. London: Bloomsbury.

Tirelli, V. 1997. Adjuncts and more adjuncts: Labor segmentation and the transformation of higher education. Social Text 51: 75-91. https://doi.org/10.2307/466648

Yates, M. 2009. Why unions matter. 2nd ed. New York: Monthly Review Press. 